\section{PENYELESAIAN SENGKETA ADMINISTRASI PEMILIHAN UMUM ${ }^{1}$ \\ Oleh : Chrisandy M. Polii ${ }^{2}$ \\ Cevonie M. Ngantung ${ }^{3}$ \\ Rudy M. K. Mamangkey ${ }^{4}$}

\section{ABSTRAK}

Tujuan dilakukannya penelitian ini adalah untuk mengetahui bagaimana sengketa administrasi yang timbul dalam proses pemilihan umum dan bagaimana penyelesaiannya menurut UndangUndang No. 7 Tahun 2017. Dengan menggunakan metode peneltian yuridis normatif, disimpulkan: 1. Pelanggaran administrasi tidak bisa dilakukan oleh badan atau orang yang tidak menyelenggarakan urusan administrasi (negara). Selanjutnya, adanya duplikasi penanganan pelanggaran administrasi oleh KPU dan Bawaslu juga perlu disempurnakan. Peraturan KPU yang menyebutkan bahwa KPU merupakan pelapor dan terlapor terhadap dugaan pelanggaran administrasi terdengar janggal, meskipun dapat dimaknai bahwa hal tersebut merupakan konsekuensi pengawasan internal secara berjenjang antara atasan dan bawahannya. Namun mengingat telah dibentuk lembaga pengawas eksternal, yaitu Bawaslu, maka seharusnya pengaduan atau laporan terhadap dugaan pelanggaran administrasi ditujukan kepada Bawaslu untuk ditindaklanjuti. 2. Penyelesaian sengketa pemilihan umum di Indonesia dapat diselesaikan oleh Badan Pengawas Pemilu, Peradilan Tata Usaha Negara dan Mahkamah Konstitusi, bila terjadi sengketa proses pemilihan umum dapat diselesaikan Badan Pengawas Pemilu dan Peradilan Tata Usaha Negara, lain halnya dengan sengketa hasil pemilihan umum dapat diselesaikan Mahkamah Konstitusi.

Kata kunci: Penyelesaian Sengketa, Administrasi, Pemilihan Umum

\section{PENDAHULUAN}

\section{A. Latar Belakang}

Pemilihan Umum juga merupakan sarana dari pelaksanaan kedaulatan rakyat yang

\footnotetext{
${ }^{1}$ Artikel Skripsi

2 Mahasiswa pada Fakultas hukum Unsrat, NIM: 16071101431

${ }^{3}$ Fakultas Hukum Unsrat, Magister IImu Hukum

${ }^{4}$ Fakultas Hukum Unsrat, Magister Ilmu Hukum
}

diselenggarakan secara langsung, umum, bebas, rahasia, jujur dan adil guna menghasilkan pemerintahan negara yang demokratis berdasarkan Pancasila dan UUD 1945. Sesuai dengan Pasal 2 ayat (1) UUD 1945 menyatakan bahwa "Kedaulatan berada ditangan rakyat dan dilaksanakan menurut Undang Undang Dasar". ${ }^{5}$ Makna dari kedaulatan ditangan Rakyat ini ialah rakyat memiliki kedaulatan, tanggungjawab, hak dan kewajiban untuk secara demokratis memilih pemimpin yang akan membentuk pemerintahan, guna mengurus dan melayani seluruh lapisan masyarakat, untuk mengawasi jalannya pemerintahan. Dan yang menjalankan kedaulatan rakyat itu adalah lembaga perwalikan rakyat yang disebut parlemen. ${ }^{6}$

Dalam pelaksanaan pemilu meskipun telah ada undang-undang serta peraturan yang khusus mengatur tentang pelaksanaan pemilu supaya dapat berjalan dengan baik namun masih juga terjadi pelanggaran dan kecurangan. Pelanggaran dan kecurangan ada yang dilakukan oleh penyelenggara pemilu, oleh peserta pemilu dan bahkan oleh masyarakat. Oleh karena itu diperlukan adanya suatu pengawasan supaya pemilu benar-benar dapat dilaksanakan berdasarkan asas langsung, umum, bebas, rahasia, jujur, dan adil. ${ }^{7}$

Pada tahun 2019, cukup banyak perkara yang ditangani atau diputus oleh Panwas Kabupaten/Kota khususnya di Provinsi Sulawesi Utara. Dari total 6.649 laporan dan temuan yang masuk, terdapat 4.759 adalah kasus pelanggaran administrasi dan 548 lainnya adalah pelanggaran pidana Pemilihan Umum (Pemilu). ${ }^{8}$ Selain itu, Bawaslu juga melakukan proses terhadap 107 pelanggaran kode etik penyelenggara pemilu. Sementara 105 pelanggaran masih diproses dan belum

\footnotetext{
${ }^{5}$ Undang- undang Dasar 1945

6 Jimly Asshiddiqie, 2010. Pengantar Ilmu Hukum Tata Negara, PT. RajaGrafindo Persada, Jakarta. h. 414

www.repository.usu.ac.id/123456789/31378/4/Chapter\% 20l.pdf, diakses pada tanggal 3 Desember 2019, Universitas Sumatera Utara.

${ }^{8}$ Kumparan.com, 2019. Ada 6.649 Laporan dan Temuan yang Diproses Bawaslu Sulut. https://kumparan.com/manadobacirita/ada-6-649laporan-dan-temuan-yang-diproses-bawaslu sulut1qpWmDiPal1
} 
dikategorikan, ${ }^{9}$ serta masih banyak lagi kasuskasus pelanggaran administrasi pemilu yang terjadi di daerah-daerah lainnya. Permaslahan ini menjadi menarik untuk dikaji berdasarkan aspek hukum administrasi maupun hukum tata negara yang berlaku di Indonesia.

Persoalan di atas merupakan masalah hukum pemilu yang semakin lama kerap terjadi dan kian pelik. Problematika ini merupakan suatu sengketa dalam pemilu yang semestinya ada mekanisme yang jelas dan kongkrit dalam proses penyelesaiannya. Oleh karena itu, dalam skripsi ini penulis mencoba mengkaji sengketa administrasi yang timbul dalam proses Pemilu serta penyelesaiannya menurut UU No. 7 Tahun 2017 tentang Pemilihan Umum (UU Pemilu), dengan harapan sistem pemilu Indonesia akan menjadi lebih baik.

\section{B. Rumusan Masalah}

1. Bagaimana sengketa administrasi yang timbul dalam proses pemilihan umum

2. Bagaimana penyelesaiannya menurut Undang-Undang No. 7 Tahun 2017?

\section{Metode Penelitian}

Jenis penelitian yang digunakan adalah yuridis normatif. Penelitian yuridis normatif yaitu penelitian hukum yang dilakukan dengan cara meneliti bahan pustaka dan data sekunder yang ada. ${ }^{10}$

\section{PEMBAHASAN}

\section{A. Sengketa Administrasi Yang Timbul Dalam Proses Pemilu}

Sengketa dalam proses pemilu umumnya terjadi di antara para peserta pemilu. Selain itu sengketa dapat juga terjadi antara peserta pemilu dengan penyelenggara pemilu sebagai akibat dikeluarkannya keputusan KPU, KPU Provinsi dan/atau KPU Kabupaten/Kota. Berdasarkan Pasal 93 Undang-Undang Nomor 7 Tahun 2017 tentang Pemilihan Umum (UU Pemilu), penindakan sengketa dalam proses pemilihan umum dilakukan oleh Badan Pengawas Pemilu (Bawaslu).

Dalam melakukan pencegahan dan penindakan, tugas Bawaslu terbagi menjadi dua

\footnotetext{
${ }^{9}$ Ibid

${ }^{10}$ Soerjono Soekanto dan Sri Mamudji, 2009. Penelitian Hukum Normatif Suatu Tinjauan Singkat, Cetakan ke - 11. Jakarta: PT Raja Grafindo Persada, h. 13
}

yaitu untuk melakukan penindakan atas pelanggaran pemilu dan penindakan atas sengketa proses pemilu. Terdapat tiga pelanggaran pemilu yaitu pelanggaran administrasi, pelanggaran kode etik dan pelanggaran tindak pidana pemilu. Pelanggaran Pemilu Contoh kasus pelanggaran administrasi pemilu seperti kampanye yang didukung dengan pemanfaatan fasilitas atau aset milik negara. Selain itu, kampanye dengan membawa anak di bawah umur juga merupakan pelanggaran. Atas pelanggaran administrasi pemilu, Bawaslu memeriksa, mengkaji dan memutus pelanggaran terkait. Putusan Bawaslu dapat berupa sanksi administratif pembatalan calon. ${ }^{11}$

Dalam pelanggaran kode etik oleh penyelenggara pemilu seperti KPU dan Bawaslu, pelanggaran tersebut diselesaikan oleh Dewan Kehormatan Penyelenggara Pemilu (DKPP). DKPP kemudian melakukan sidang untuk selanjutnya menetapkan putusan DKPP. Putusan biasanya berupa sanksi atau rehabilitasi diambil dalam rapat pleno DKPP. Sedangkan yang termasuk pelanggaran tindak pidana pemilu yaitu melakukan politik uang atau biasa disebut Money Politics. Pelanggaran tindak pidana pemilu selanjutnya diselesaikan dalam peradilan umum sesuai dengan hukum acara pidana. Sengketa Proses Pemilu Pada sengketa proses pemilu, sengketa dibawa oleh pemohon kepada Bawaslu untuk dikaji.

\section{B. Penyelesaian Sengketa Admistrasi Proses Pemilihan Umum menurut Undang-Undang Nomor 7 Tahun 2017}

Undang-Undang Nomor 7 Tahun 2017 tentang Pemilihan Umum mengatur tentang pokok-pokok yang menjadi ruang lingkup dan mekanisme penegakan pelanggaran pemilu, sengketa proses pemilu, dan perselisihan hasil pemilu. Adapun mekanisme penyelesaian sengketa proses pemilu dibedakan menjadi dua mekanisme yaitu: pertama, mekanisme penyelesaian sengketa proses Pemilu di Bawaslu, Bawaslu Provinsi, dan Bawaslu Kabupaten/Kota yang diatur dalam Pasal 466

\footnotetext{
${ }^{11}$ Zarra Nur Alyani. 2019. Sengketa Dalam Proses Pemilu, diakses melalui https://smartlegal.id/smarticle/2019/03/06/sengketadalam-proses-pemilu-yang-harus-anda-ketahui/ pada tanggal 29 September 2019
} 
sampai dengan Pasal 469 Undang-Undang Nomor 7 Tahun 2017; dan kedua, mekanisme penyelesaian sengketa proses pemilu di Pengadilan Tata Usaha Negara yang diatur dalam Pasal 470 sampai dengan Pasal 472 Undang-Undang Nomor 7 Tahun 2017.

Pengaturan lebih lanjut terkait ruang lingkup dan mekanisme penyelesaian sengketa proses Pemilu di Bawaslu diatur melalui Peraturan Badan Pengawas Pemilihan Umum Republik Indonesia Nomor 18 Tahun 2017 tentang Tata Cara Penyelesaian Sengketa Proses Pemilihan Umum, Peraturan Badan Pengawas Pemilihan Umum Republik Indonesia Nomor 18 Tahun 2018 tentang Perubahan Atas Peraturan Badan Pengawas Pemilihan Umum Nomor 18 Tahun 2017 tentang Tata Cara Penyelesaian Sengketa Proses Pemilihan Umum, Peraturan Bawaslu Nomor 27 Tahun 2018 tentang Perubahan Kedua Peraturan Badan Pengawas Pemilihan Umum Nomor 18 Tahun 2017 tentang Tata Cara Penyelesaian Sengketa Proses Pemilihan Umum, dan Peraturan Bawaslu Nomor 5 Tahun 2019 tentang Perubahan Ketiga Atas Peraturan Badan Pengawas Pemilihan Umum Nomor 18 Tahun 2018 tentang Tata Cara Penyelesaian Sengketa Proses Pemilu. ${ }^{12}$

Dengan demikian jika dirinci maka dasar hukum yang digunakan sebagai hukum acara penyelesaian sengketa proses Pemilu adalah sebagai berikut:

1. Undang-Undang Nomor 7 Tahun 2017 tentang Pemilihan Umum ${ }^{13}$

2. Perbawaslu Republik Indonesia Nomor 18 Tahun 2017 tentang Tata Cara Penyelesaian Sengketa Proses Pemilihan Umum $^{14}$

3. Perbawaslu Republik Indonesia Nomor 18 Tahun 2018 tentang Perubahan Atas Perbawaslu Nomor 18 Tahun 2017 tentang Tata Cara Penyelesaian Sengketa Proses Pemilihan Umum ${ }^{15}$

\footnotetext{
12 Keseluruhan Perbawaslu ini disingkat dengan Perbawaslu tentang Tata Cara Penyelesaian Sengketa Proses Pemilu

13 Lembaran Negara Republik Indonesia Tahun 2017 Nomor 182, Tambahan Lembaran Negara Republik Indonesia Nomor 6109

${ }^{14}$ Berita Negara Republik Indonesia Tahun 2017 Nomor 1862

${ }^{15}$ Berita Negara Republik Indonesia Tahun 2018 Nomor 787
}

4. Perbawaslu Nomor 27 Tahun 2018 tentang Perubahan Kedua Atas Perbawaslu Nomor 18 Tahun 2017 tentang Tata Cara Penyelesaian Sengketa Proses Pemilihan Umum ${ }^{16}$

5. Perbawaslu Nomor 5 Tahun 2019 tentang Perubahan Ketiga Atas Perbawaslu Nomor 18 Tahun 2017 tentang Tata Cara Penyelesaian Sengketa Proses Pemilu ${ }^{17}$

Ketentuan Pasal 1 angka 22 Perbawaslu tentang Tata Cara Penyelesaian Sengketa Proses Pemilu mendefinisikan Pemohon sebagai pihak yang mengajukan Permohonan sengketa proses Pemilu. Lebih lanjut konstruksi kedudukan hukum (legal standing) Pemohon sengketa proses Pemilu terangkai dalam ketentuan Pasal 7, Pasal 7A, dan Pasal 7B Perbawaslu tentang Tata Cara Penyelesaian Sengketa Proses Pemilu. Adapun Pemohon sengketa proses Pemilu terdiri atas: ${ }^{18}$ (a) partai politik calon Peserta Pemilu yang telah mendaftarkan diri sebagai Peserta Pemilu di KPU; (b) Partai Politik Peserta Pemilu; (c) bakal calon anggota DPR dan DPRD yang telah mendaftarkan diri kepada KPU; (d) calon anggota DPR dan DPRD yang tercantum dalam daftar calon tetap; (e) bakal calon Anggota DPD yang telah mendaftarkan diri kepada KPU; (f) calon anggota DPD; (g) bakal Pasangan Calon; dan (h) Pasangan Calon.

Lebih lanjut Pasal 7A Perbawaslu tentang Tata Cara Penyelesaian Sengketa Proses Pemilu menentukan bahwa: "Permohonan penyelesaian sengketa proses Pemilu yang diajukan oleh partai politik calon Peserta Pemilu dan/atau Partai Politik Peserta Pemilu dilakukan dengan ketentuan sebagai berikut: (a) tingkat pusat diajukan oleh ketua umum dan sekretaris jenderal partai atau sebutan lain; (b) tingkat provinsi diajukan oleh ketua dan sekretaris tingkat provinsi atau sebutan lain; dan (c) tingkat kabupaten/kota diajukan oleh ketua dan sekretaris tingkat kabupaten/kota atau sebutan lain."

\footnotetext{
${ }^{16}$ Berita Negara Republik Indonesia Tahun 2018 Nomor 1098

17 Berita Negara Republik Indonesia Nomor 419 Tahun 2019

18 Pasal 7 ayat (1) Perbawaslu tentang Tata Cara Penyelesaian Sengketa Proses Pemilu
} 
Mengenai Termohon dalam sengketa proses Pemilu merujuk pada pada rumusan Pasal 466 UU Pemilu juncto Pasal 1 angka 23 dan Pasal 8 Perbawaslu tentang Tata Cara Penyelesaian Sengketa Proses Pemilu. Pasal 466 UU Pemilu berbunyi: "Sengketa proses Pemilu meliputi sengketa yang terjadi antar-Peserta Pemilu dan sengketa Peserta Pemilu dengan Penyelenggara Pemilu sebagai akibat dikeluarkannya keputusan KPU, keputusan KPU Provinsi, dan keputusan KPU Kabupaten/Kota".

Sedangkan ketentuan Pasal 1 angka 23 Perbawaslu tentang Tata Cara Penyelesaian Sengketa Proses Pemilu menyatakan: "Termohon adalah pihak yang diajukan di dalam Permohonan sengketa proses Pemilu". Lebih lanjut, Pasal 8 Perbawaslu tentang Tata Cara Penyelesaian Sengketa Proses Pemilu menguraikan secara rinci tentang Termohon penyelesaian sengketa proses Pemilu dengan menyatakan bahwa Termohon dalam sengketa proses Pemilu terdiri atas: (1 KPU, KPU Provinsi, atau KPU Kabupaten/Kota untuk sengketa antara peserta dengan penyelenggara Pemilu; dan (2) Partai Politik Peserta Pemilu, calon Anggota DPR, DPD, dan DPRD, atau Pasangan Calon untuk sengketa antarpeserta. Adapun mengenai Termohon sengketa proses Pemilu yang terjadi antarPeserta mengacu pada Pasal 3 dan Pasal 4 ayat (1) Perbawaslu tentang Tata Cara Penyelesaian Sengketa Proses Pemilu, yaitu: Partai Politik atau Calon anggota DPR, DPD, dan DPRD yang oleh tindakannya dianggap merugikan hak Pemohon sebagai Peserta Pemilu. Sedangkan Termohon sengketa proses Pemilu yang terjadi antara Peserta Pemilu dengan Penyelenggara Pemilu yaitu: KPU, KPU Provinsi dan KPU Kabupaten/Kota yang tindakannya dianggap merugikan hak Pemohon sebagai Peserta Pemilu. ${ }^{19}$

Sedangkan Pihak Terkait dalam penyelesaian sengketa proses Pemilu diatur dalam Pasal 9 ayat (1) dan ayat (2) Perbawaslu tentang Tata Cara Penyelesaian Sengketa Proses Pemilu, bahwa: (1) Partai Politik Peserta Pemilu, calon anggota DPR dan DPRD yang tercantum di dalam DCT, calon anggota DPD, atau Pasangan Calon yang berpotensi dirugikan atas

\footnotetext{
${ }^{19}$ Dalam hal sengketa proses yang terjadi antara Peserta Pemilu dengan Penyelenggara Pemilu, tindakan yang dimaksud adalah tindakan KPU, KPU Provinsi dan KPU Kabupaten/Kota dalam mengeluarkan keputusan.
}

penyelesaian sengketa proses Pemilu dapat mengajukan diri sebagai pihak terkait. (2) Pengajuan diri sebagai pihak terkait bagi calon anggota DPR dan DPRD sebagaimana dimaksud pada ayat (1) melalui Partai Politik.

Berkaitan dengan objek sengketa (objectum litis) Penyelesaian Sengketa Proses Pemilu diatur lebih lanjut dalam Perbawaslu tentang Tata Cara Penyelesaian Sengketa Proses Pemilu yang bertolak dari konstruksi Pasal 466 UU Pemilu, mengkualifisir bahwa sengketa proses Pemilu terjadi karena: (a) hak peserta Pemilu yang dirugikan secara langsung oleh tindakan peserta Pemilu lain sebagai akibat dikeluarkannya keputusan KPU, keputusan KPU Provinsi, atau keputusan KPU Kabupaten/Kota; atau (b) hak peserta Pemilu yang dirugikan secara langsung oleh tindakan KPU, KPU Provinsi, atau KPU Kabupaten/Kota, sebagai akibat dikeluarkannya keputusan KPU, keputusan KPU Provinsi, atau keputusan KPU Kabupaten/Kota.

Ketentuan Pasal 4 ayat (2) Perbawaslu tentang Tata Cara Penyelesaian Sengketa Proses Pemilu merumuskan tentang bentuk dan jenis objek sengketa proses Pemilu bahwa: "Keputusan KPU, keputusan KPU Provinsi, atau keputusan KPU Kabupaten/Kota sebagaimana dimaksud pada ayat (1) berupa surat keputusan dan/atau berita acara". Adapun pembatasan/pengecualian keputusan KPU, keputusan KPU Provinsi, keputusan KPU Kabupaten/Kota yang tidak dapat dijadikan sebagai objek sengketa dirumuskan dalam Pasal 4A ayat (1) serta Pasal 12 ayat (3) dan ayat (4) Perbawaslu tentang Tata Cara Penyelesaian Sengketa Proses Pemilu, sebagai berikut:

(1) bahwa Keputusan sebagaimana dimaksud dalam Pasal 4 ayat (2) yang tidak dapat dijadikan objek sengketa antara lain:

a. surat keputusan atau berita acara KPU, KPU Provinsi dan KPU Kabupaten/Kota yang merupakan tindak lanjut dari Putusan Pelanggaran Administratif Pemilu atau Putusan Penyelesaian Sengketa Proses Pemilu oleh Bawaslu, Bawaslu Provinsi, atau Bawaslu Kabupaten/Kota; 
b. surat keputusan atau berita acara KPU, KPU Provinsi dan KPU Kabupaten/Kota yang merupakan tindak lanjut dari penanganan sentra penegakan hukum terpadu atau putusan pengadilan terkait Tindak Pidana Pemilu yang telah memperoleh kekuatan hukum yang tetap; atau

c. surat keputusan atau berita acara KPU, KPU Provinsi dan KPU Kabupaten/Kota yang merupakan hasil penghitungan suara, rekapitulasi hasil penghitungan suara, dan penetapan hasil Pemilu. ${ }^{20}$

(2) Permohonan sebagaimana dimaksud pada ayat (1):

a. belum pernah diregister pada proses penanganan dugaan pelanggaran administratif Pemilu dan penanganan dugaan tindak pidana Pemilu kepada Bawaslu, Bawaslu Provinsi dan Bawaslu Kabupaten/Kota.

b. bukan merupakan sengketa yang terjadi antara calon peserta Pemilu dalam satu Partai Politik. ${ }^{21}$

Mekanisme penyelesaian sengketa harus dilakukan sesuai dengan ketentuan UU Pemilu juncto Perbawaslu tentang Tata Cara Penyelesaian Sengketa Proses Pemilu. Khusus untuk penyelesaian sengketa proses Pemilu yang terjadi antara peserta Pemilu dengan Penyelenggara Pemilu, pengajuan permohonan dilakukan dengan jangka waktu, yaitu paling lama 3 (tiga) hari kerja sejak tanggal penetapan keputusan KPU, KPU Provinsi, atau KPU Kabupaten/Kota. ${ }^{22}$ Apabila permohonan diajukan melebihi jangka waktu maka Bawaslu, Bawaslu Provinsi, atau Bawaslu Kabupaten/Kota menyatakan permohonan

\footnotetext{
${ }^{20}$ Perbawaslu tentang Tata Cara Penyelesaian Sengketa Proses Pemilu, Pasal 4A ayat (1). Perbawaslu tentang Tata Cara Penyelesaian Sengketa Proses Pemilu Pasal 4A ayat (2) kemudian mengatur lebih lanjut bahwa: Permohonan yang diajukan dengan objek sebagaimana dimaksud pada ayat (1) dinyatakan tidak dapat diregister dan dituangkan menggunakan formulir model PSPP 07 setelah mendapatkan persetujuan dari anggota Bawaslu, Bawaslu Provinsi, atau Bawaslu Kabupaten/Kota

${ }^{21}$ Perbawaslu tentang Tata Cara Penyelesaian Sengketa Proses Pemilu, Pasal 12 ayat (3) dan ayat (4). Calon Peserta Pemilu yang dimaksud adalah calon anggota DPR, DPRD Provinsi, atau DPRD Kabupaten/Kota

22 Ibid, Pasal 12 ayat (2)
}

tidak dapat diterima. ${ }^{23}$ Apabila permohonan yang diajukan telah memenuhi syarat formil dan materil maka permohonan tersebut diregister.

Bawaslu, Bawaslu Provinsi dan Bawaslu Kabupaten/Kota memiliki waktu paling lama 12 hari kerja untuk menyelesaikan sengketa yang terjadi antara peserta dengan penyelenggara Pemilu dengan prosedur mediasi dan adjudikasi. Mediasi merupakan mekanisme penyelesaian sengketa untuk mencapai kesepakatan para pihak, jika tidak terjadi kesepakatan atau mufakat antara para Pihak, maka dilanjutkan dengan mekanisme adjudikasi. Terhadap putusan adjudikasi yang diterbitkan oleh Bawaslu Provinsi atau Bawaslu Kabupaten/Kota yang tidak memuaskan pihak Pemohon, maka Pemohon dapat melakukan upaya administrasi melalui pengajuan permohonan Koreksi Putusan paling lama 1 (satu) hari kerja setelah putusan Bawaslu Provinsi dan/atau Bawaslu Kabupaten/Kota dibacakan.

Bawaslu memiliki waktu paling lama 2 (dua) hari kerja sejak permohonan koreksi di register, untuk menerbitkan hasil koreksi. Sedangkan penyelesaian sengketa proses pemilu antar Peserta dilakukan melalui mekanisme acara cepat dengan cara musyawarah yang apabila kesepakatan tidak tercapai diantara para pihak maka Pengawas Pemilu memiliki wewenang untuk secara langsung menerbitkan keputusan.

Adapun dasar hukum penyusunan laporan akhir penyelesaian sengketa proses Pemilu merujuk pada ketentuan Pasal 96 huruf c UU Pemilu yang menyatakan bahwa: "Bawaslu berkewajiban menyampaikan laporan hasil pengawasan kepada presiden dan DPR sesuai dengan tahapan Pemilu secara periodik dan/atau berdasarkan kebutuhan", serta ketentuan Pasal 45 Perbawaslu tentang Tata Cara Penyelesaian Sengketa Proses Pemilu yang menentukan bahwa: "penyelesaian sengketa proses pemilu yang diselesaikan oleh Bawaslu Provinsi dan Bawaslu Kabupaten/Kota dilaporkan kepada Bawaslu secara berjenjang sesuai dengan tingkatannya terdiri atas: (a) laporan awal; (b) laporan proses; (c) laporan akhir; (d) laporan tahunan; dan (e) laporan akhir tahapan Pemilu"

\footnotetext{
${ }^{23}$ Ibid, Pasal 13 ayat (4)
} 
Selanjutnya ketentuan dalam UndangUndang Nomor 7 Tahun 2017 tentang Pemilihan Umum menentukan bahwa Bawaslu bertugas melakukan pencegahan dan penindakan terhadap sengketa proses pemilu. ${ }^{24}$ Dalam melakukan penindakan sengketa proses Pemilu, Bawaslu bertugas: (a) menerima permohonan penyelesaian sengketa proses Pemilu; (b) memverifikasi secara formal dan materiel permohonan penyelesaian sengketa proses Pemilu; (c) melakukan mediasi antar pihak yang bersengketa; (d) melakukan proses adjudikasi sengketa proses Pemilu; dan (e) memutus penyelesaian sengketa proses Pemilu. ${ }^{25}$ Ditegaskan pula bahwa Bawaslu berwenang menerima, memeriksa, memediasi atau mengadjudikasi, dan memutus penyelesaian sengketa proses Pemilu, ${ }^{26}$ serta mengoreksi putusan dan rekomendasi Bawaslu Provinsi dan Bawaslu Kabupaten/Kota apabila terdapat hal yang bertentangan dengan ketentuan peraturan perundang-undangan. ${ }^{27}$

Adapun kewenangan penyelesaian sengketa proses Pemilu yang dilakukan oleh Bawaslu berkaitan dengan dikeluarkannya keputusan KPU sebagaimana ditentukan dalam Pasal 5 ayat (1) Perbawaslu tentang tata Cara Penyelesaian Sengketa Proses Pemilu bahwa "Bawaslu berwenang menyelesaikan sengketa proses Pemilu yang diakibatkan oleh adanya keputusan KPU". Dengan demikian kompetensi relatif dari kewenangan penyelesaian sengketa proses Pemilu yang dilakukan oleh Bawaslu hanya terhadap keputusan yang dikeluarkan oleh KPU.

Bawaslu provinsi melalui ketentuan dalam Undang-Undang Nomor 7 Tahun 2017 tentang Pemilihan Umum menentukan bahwa "Bawaslu Provinsi bertugas melakukan pencegahan dan penindakan di wilayah provinsi terhadap sengketa proses pemilu". ${ }^{28}$

Dalam melakukan penindakan sengketa proses Pemilu, Bawaslu Provinsi bertugas:

\footnotetext{
${ }^{24}$ UU Pemilu, Pasal 93 huruf $b$ angka 2. Lihat pula Perbawaslu tentang Tata Cara Penyelesaian Sengketa proses pemilu, Pasal 5 ayat (4).

${ }^{25}$ UU Pemilu, Pasal 94 ayat (3)

${ }^{26}$ UU Pemilu, Pasal 95 huruf $d$

${ }^{27}$ UU Pemilu, Pasal 95 huruf $h$

28 UU Pemilu, Pasal 97 huruf a angka 2. Lihat pula Perbawaslu tentang Tata Cara Penyelesaian Sengketa Proses Pemilu, Pasal 5 ayat (4).
}

(a) menerima permohonan penyelesaian sengketa proses Pemilu di wilayah provinsi;

(b) memverifikasi secara formal dan materiel permohonan penyelesaian sengketa proses Pemilu di wilayah provinsi

(c) melakukan mediasi antarpihak yang bersengketa di wilayah provinsi;

(d) melakukan proses adjudikasi sengketa proses Pemilu di wilayah provinsi apabila mediasi belum menyelesaiakan sengketa proses Pemilu; dan

(e) memutus penyelesaian sengketa proses Pemilu di wilayah provinsi. ${ }^{29}$

\section{PENUTUP}

\section{A. Kesimpulan}

Berdasarkan hasil analisis di atas, dapat ditarik kesimpulan bahwa salah satu hal yang penting untuk diperhatikan adalah pelanggaran administrasi tidak bisa dilakukan oleh badan atau orang yang tidak menyelenggarakan urusan administrasi (negara). Selanjutnya, adanya duplikasi penanganan pelanggaran administrasi oleh KPU dan Bawaslu juga perlu disempurnakan. Peraturan KPU yang menyebutkan bahwa KPU merupakan pelapor dan terlapor terhadap dugaan pelanggaran administrasi terdengar janggal, meskipun dapat dimaknai bahwa hal tersebut merupakan konsekuensi pengawasan internal secara berjenjang antara atasan dan bawahannya. Namun mengingat telah dibentuk lembaga pengawas eksternal, yaitu Bawaslu, maka seharusnya pengaduan atau laporan terhadap dugaan pelanggaran administrasi ditujukan kepada Bawaslu untuk ditindaklanjuti.

Penyelesaian sengketa pemilihan umum di Indonesia dapat diselesaikan oleh Badan Pengawas Pemilu, Peradilan Tata Usaha Negara dan Mahkamah Konstitusi, bila terjadi sengketa proses pemilihan umum dapat diselesaikan Badan Pengawas Pemilu dan Peradilan Tata Usaha Negara, lain halnya dengan sengketa hasil pemilihan umum dapat diselesaikan Mahkamah Konstitusi.

\section{B. Saran}

1. Perlu dilakukan revisi terhadap UndangUndang Nomor 7 Tahun 2017 tentang

\footnotetext{
${ }^{29}$ UU Pemilu, Pasal 98 ayat (3)
} 
Pemilu, khusus yang berkaitan dengan desain penegakan hukum penyelesaian sengketa proses Pemilu yang terjadi antarPeserta Pemilu. Sebab, konstruksi norma dalam Pasal 466 sampai dengan Pasal 469 mengandung sejumlah kelemahan, antara lain: (1) Konstruksi ruang lingkup penyelesaian sengketa antarPeserta Pemilu pada Pasal 466 yang mengaitkan objek sengketa proses Pemilu sebagai akibat diterbitkannya Keputusan Penyelenggara Pemilu. Dengan konstruksi demikian, esensi sengketa antarPeserta menjadi tidak relevan karena yang mengeluarkan objek sengketa adalah Penyelenggara Pemilu tetapi yang disengketakan adalah Peserta Pemilu; dan (2) Mekanisme penyelesaian sengketa antarPeserta Pemilu memiliki karakteristik yang berbeda dengan sengketa antara Peserta Pemilu dengan Penyelenggara Pemilu sehingga perlu pangaturan mekanisme penyelesaian yang berbeda.

2. Diperlukan penyamaan persepsi antara Bawaslu dengan Mahkamah Agung terkait upaya hukum penyelesaian sengketa proses Pemilu yang dilakukan oleh Pengadilan Tata Usaha Negara agar dapat memberikan pemenuhan akses penyelesaian sengketa proses Pemilu bagi pencari keadilan Pemilu.

\section{DAFTAR PUSTAKA}

Abdulkadir M, 2004. Hukum dan Penelitian Hukum. Citra Aditya Bakti, Bandung

A.Ubaedillah dan Abdul Rozak, 2014. Pancasila, Demokrasi, HAM, dan Masyarakat Madani, Prenamedia Group, Jakarta

Bambang Sunggono, 2006. Metodologi Penelitian Hukum, Raja Grafindo Persada, Cet. 1, Jakarta

Gotfridus Goris Seran, 2013. Kamus Pemilu Populer: Kosa Kata Umum, Pengalaman Indonesia dan Negara Lain, Graha Ilmu: Yogyakarta

IDEA, 2010. Keadilan Pemilu: Ringkasan Buku Acuan Intenational IDEA, Penyunting CETRO, Sumut

Jimly Asshiddiqie, 2013. Menegakkan Etika Penyelenggara Pemilu. Raja Grafindo, Jakarta
Jimly Asshiddiqie, 2010. Pengantar Ilmu Hukum Tata Negara, PT. RajaGrafindo Persada, Jakarta

Jimly Asshidiqie, 2008. Menuju Negara Hukum yang Demokratis, Sekretariat Jenderal dan Kepaniteraan Mahkamah Konstitusi, Jakarta

Joko J. Prihatmoko, 2008. Mendemokratiskan Pemilu, Dari Sistem Sampai Elemen Teknis, Pustaka Pelajar, Yogyakarta

Mukti Fajar, Yulianto Achmad, 2007. Dualisme Penelitian Hukum. Fakultas Hukum Universitas Muhammadiyah, Yogyakarta

Nurul Huda. 2018. Hukum Partai Politik dan Pemilu di Indonesia. Fokusmedia, Bandung

Peter M. Marzuki, 2011. Penelitian Hukum. Kencana Prenada Media Group, Jakarta

Ramlan Surbakti, 1992. Memahami Ilmu Politik, PT Gramedia Widiasarana Indonesia, Jakarta

R. Wiyono, 2007. Hukum Acara Peradilan Tata Usaha Negara, Cetakan Peratama, Sinar Grafika, Jakarta

Sodikin, 2014. Hukum Pemilu: Pemilu Sebagai Praktek Ketatanegaraan, Gramata Publishing, Jakarta

Soerjono Soekanto dan Sri Mamudji, 2009. Penelitian Hukum Normatif Suatu Tinjauan Singkat, Cetakan ke-11. PT Raja Grafindo Persada, Jakarta

Titik Triwulan Tutik, 2010. Kontruksi Hukum Tata Negara Indonesia Pasca Amandemen UUD 1945, Prenada Media Group, Jakarta

Victor M. Situmorang dan Jusuf Juhir, Aspek Hukum Pengawasan Melekat I, Rineka Cipta, Jakarta

\section{Jurnal}

Deny Wahyu Sapuro, 2018. "Tugas, Wewenang dan Fungsi Badan Pengawas Pemilu (BAWASLU) dalam Pengawasan Pemilu di Jawa Barat Berdasarkan dengan Undang-Undang No. 7 tahun 2017 tentang Pemilu", Skripsi, Universitas Pasudan: Pasudan

Firdaus, 2014. Penyelesaian Sengketa Pemilu sebagai Upaya Memulihkan Kepercayaan dan Memperkuat Legitimasi Pemerintahan Demokrasi, 
Fiat Justisia Jurnal IImu Hukum Vol.8 No.2 Tahun 2014, Fakultas Hukum Universitas Lampung

Marzuki Lubis, 2016. Kewenangan Bawaslu/Panwaslu Dalam Pilkada Serentak Pada Perspektif Hukum Tata Negara dan Demokrasi di Indonesia Terkait Dengan Revisi Undang-Undang Pilkada, Makalah Tentang Evaluasi Pilkada, Sumatra Utara

Jimly Asshiddiqie, 2013. "Pengenalan DKPP untuk Pengegak Hukum," (Forum Rapat Pimpinan Kepolisian Republik Indonesia, Kepolisian Republik Indonesia, Jakarta

Triono, "Menakar Efektifitas Pemilu Serentak 2019", Jurnal Wacana Politik Program Studi Hubungan Internasional Universitas Megou Pak Tulang Bawang, (Vol. 2, No. 2, Oktober)

W. Riawan Tjandra, 2009. Peradilan Tata Usaha Negara; Mendorong Terwujudnya Pemerintahan yang Bersih dan Berwibawa, Universitas Atma Jaya, Yogyakarta

\section{Website}

https://www.bawaslu.go.id/sites/default/files/ hasil_pengawasan/FIX\%20LAPORAN\%2 OAKHIR\%20SENGKETA\%202019.pdf www.repository.usu.ac.id/123456789/31378/4 /Chapter\%20I.pdf, diakses pada tanggal 3 Desember 2019, Universitas Sumatera Utara.

Kumparan.com, 2019. Ada 6.649 Laporan dan Temuan yang Diproses Bawaslu Sulut. https://kumparan.com/manadobacirita /ada-6-649-laporan-dan-temuan-yangdiproses-bawaslu sulut-1qpWmDiPal1

rumahpemilu.org, Rezim Penegakan Hukum Pemilu di Tangan Bawaslu yang Makin Kuat", https://rumahpemilu.org/rezimpenegakan-hukum-pemilu-di-tanganbawaslu-yang-makin-kuat/, diakses 15 September 2020

Zarra Nur Alyani. 2019. Sengketa Dalam Proses Pemilu, diakses melalui https://smartlegal.id/smarticle/2019/0 3/06/sengketa-dalam-proses-pemiluyang-harus-anda-ketahui/ pada tanggal 29 September 2019

\section{Undang-Undang dan Peraturan Lainnya}

Undang- undang Dasar 1945

Undang-Undang Nomor 7 Tahun 2017 tentang Pemilihan Umum

Lembaran Negara Republik Indonesia Tahun 2017 Nomor 182, Tambahan Lembaran Negara Republik Indonesia Nomor 6109

Berita Negara Republik Indonesia Tahun 2017 Nomor 1862

Peraturan Badan Pengawas Pemilihan Umum Republik Indonesia Nomor 7 Tahun 2017 Tentang Penanganan temuan dan laporan pelanggaran pemilihan umum

Peraturan Bawaslu Nomor 5 Tahun 2019 tentang Perubahan Ketiga atas Peraturan Bawaslu Nomor 18 Tahun 2017 tentang Tata Cara Penyelesaian Sengketa Proses Pemilu.

Peraturan Mahkamah Agung Nomor 1 Tahun 2018 tentang Tata Cara Penyelesaian Tindak Pidana Pemilihan dan Pemilihan Umum 